\title{
Breast-conserving surgery with or without radiotherapy vs mastectomy for ductal carcinoma in situ: French Survey experience
}

\begin{abstract}
B Cutuli*, I, C Lemanski ${ }^{2}$, A Fourquet ${ }^{3}$, B de Lafontan ${ }^{4}$, S Giard $^{5}$, A Meunier $^{6}$, R Pioud-Martigny $^{7}$, F Campana ${ }^{3}$, H Marsiglia ${ }^{8}$, Lancrenon $^{9}$, E Mery ${ }^{4}$, F Penault-Llorca ${ }^{10}$, E Fondrinier ${ }^{1 /}$ and C Tunon de Lara ${ }^{12}$

'Radiation Oncology Department, Polyclinique Courlancy, 38 rue Courlancy, Reims 51 100, France; '2Department of Radiation Oncology, Centre Val d'Aurelle, Montpellier Cedex 34094, France; ${ }^{3}$ Department of Radiation Oncology, Institut Curie, 26 rue d'Ulm, Paris 7523I, France; ${ }^{4}$ Department of Radiation Oncology and Pathology, Centre Claudius Regaud, 20-24 rue du Pont St Pierre, Toulouse 31052, France; ${ }^{5}$ Department of Breast Surgery, Centre Oscar Lambret, Rue F. Combemale, Lille 59020, France; ${ }^{6}$ Department of Breast Surgery, Centre Léon Bérard, 28 avenue Laennec, Lyon 69373 , France; ' Department of Breast Surgery, Centre René Gauducheau, Bd J. Monod, Nantes 44085, France; ${ }^{8}$ Department of Radiation Oncology, Institut Gustave Roussy, 39 rue C. Demoulins, Villejuif 94805, France; ${ }^{9}$ Department of Statistics, Sylia-Stat, 10 Bd Marechal Joffre, Bourg-la-Reine 92340, France; ${ }^{10}$ Department of Pathology, Centre Jean Perrin, 30 Place H. Dunant, Clermont-Ferrand 630 II, France; " Department of Surgery, Centre Paul Papin,

2 rue Moll, Angers 49036, France; ${ }^{12}$ Department of Breast Surgery, Institut Bergonie, 229 Cours de l'Argonne, Bordeaux 33076, France
\end{abstract}

From March 2003 to April 2004, 77 physicians throughout France prospectively recruited I289 ductal carcinoma in situ (DCIS) patients and collected data on diagnosis, patient and tumour characteristics, and treatments. Median age was 56 years (range, 30-84). Ductal carcinoma in situ was diagnosed by mammography in $87.6 \%$ of patients. Mastectomy, conservative surgery alone (CS) and CS with radiotherapy (CS + RT) were performed in 30.5, 7.8 and $61.7 \%$ of patients, respectively. Thus, $89 \%$ of patients treated by CS received adjuvant RT. Sentinel node biopsy (SNB) and axillary dissection (AD) were performed in 21.3 and $10.4 \%$ of patients, respectively. Hormone therapy was administered to $13.4 \%$ of the patients ( $80 \%$ tamoxifen). Median tumour size was $14.5 \mathrm{~mm}$ (6, II and $35 \mathrm{~mm}$ for CS, CS +RT and mastectomy, respectively, $P<0.000 \mathrm{I}$ ). Nuclear grade was high in $21 \%$ of patients, intermediate in $38.5 \%$ and low in $40.5 \%$. Excision was considered complete in $92 \%$ (CS) and $88.3 \%$ (CS + RT) of patients. Oestrogen receptors were positive in $69.8 \%$ of assessed cases (31\%). Treatment modalities varied widely according to region: mastectomy rate, 20-37\%; adjuvant RT, 84-96\%; hormone treatment, 6-34\%. Our survey on current DCIS management in France has highlighted correlations between pathological features (tumour size, margin and grade) and treatment options, with several similar variations to those observed in recent UK and US studies.

British Journal of Cancer (2009) I 00, 1048- 1054. doi: I0.1038/sj.bjc.6604968 www.bjcancer.com

Published online 10 March 2009

(c) 2009 Cancer Research UK

Keywords: breast carcinoma; ductal carcinoma in situ; mastectomy; breast-conserving surgery; radiotherapy; tamoxifen

In France, 49.236 new breast cancers were diagnosed in women in 2004 (Allemand et al, 2008). Between 2000 and 2004, the annual incidence rate increased by $2 \%$. However, the precise proportion of ductal carcinoma in situ (DCIS) in France is unknown. Presently, DCIS accounts for approximately $15-20 \%$ of all breast cancers (Baxter et al, 2004; Leonard and Swain, 2004). The French screening programme was introduced in several counties (départements) in 1989 and was progressively extended all over France within the framework of the National Cancer Plan in 2000. The national coverage was achieved in 2005. Ductal carcinoma in situ rate among abnormal screen-detected mammographies reached $13.8 \%$. Ductal carcinoma in situ is treated by mastectomy or conservative surgery (CS) with or without radiotherapy (RT) (Morrow et al, 2002; Ceilley et al, 2004; Mokbel and Cutuli, 2006). The best option is still a matter of debate, with wide differences in practice observed across European countries and the United States

*Correspondence: Dr B Cutuli; E-mail: bcutuli@oncorad.courlancy.fr This paper was partly presented at the XIII European Cancer Conference in Paris on I November 2005, and at the XXVIII French Congress of Senology in November 2006.

Received 23 September 2008; revised 2 February 2009; accepted 4 February 2009; published online 10 March 2009
(Ceilley et al, 2004; Mokbel and Cutuli, 2006). Moreover, important regional differences were also reported.

Up-to-date data on DCIS are not available for France. We therefore performed a national prospective survey of the diagnosis, histopathological features and treatment of pure DCIS in France and compared our findings with those from other countries. The methodology of this survey was similar to a study on invasive breast cancer conducted in 2001-2002 (Cutuli et al, 2006).

\section{MATERIALS AND METHODS}

Our observational, prospective cross-sectional study was performed from March 2003 to April 2004. A total of 77 physicians took part in the study and were recruited in surgery, oncology and radiation oncology departments throughout France. Most of them participated in the first national survey on infiltrating breast cancer in 2001-2002 (Cutuli et al, 2006). Those physicians are coordinators of a local breast unit, or general or gynaecological surgeons involved in breast cancer care. Finally, they are usually good representatives of all French regions (urban and rural) and types of sanitary structures. Indeed, patients were managed in cancer centres ( $49 \%$ of patients), private clinics $(33 \%)$, or 
university or general hospitals (18\%), reflecting quite well the daily current practice in our country. All patients seen in each hospital were prospectively included, but obviously with a more important recruitment in several specialized centres ( 7 with more than 50 cases each).

Eligibility criteria were female gender, $\geqslant 18$ years of age, with a diagnosis of pure DCIS. Patients with microinvasive lesions, previous or synchronous contralateral breast cancer or other cancers were excluded.

We collected data on demographics (age, family history of breast cancer, menopausal status, hormonal replacement therapy (HRT)), clinical presentation, mammography findings, biopsy procedures, specimen characteristics as given by the pathology report (tumour subtype, size, grade, excision quality and hormone receptor status) and treatment (types of surgery, number of operations, adjuvant therapy (RT with or without boost and hormone therapy) (see form in Supplementary Information). All data were checked (exhaustive pathological forms, radiation doses and other treatments) by the first author in collaboration with two pathologists of the scientific committee (FP-L, EM) and the statistical team, especially regarding some cases of 'incoherencies'. The individual survey forms were made by each physician who sent them to the data management centre.

\section{Statistical methods}

We used SAS software (version 8.2, SAS Institute Inc., Cary, NC, USA).

To compare two groups, we used the $\chi^{2}$ test for categorical variables, the $t$-test for continuous variables and the nonparametric Mann - Whitney test when the assumption of normality was questionable. To compare more than two groups, we used the $\chi^{2}$ test for categorical variables, one-way analysis of variance for continuous variables and the non-parametric Kruskal-Wallis test when the assumption of normality was questionable. Three treatment groups were compared, namely CS alone (99 patients: 7.8\%), CS + RT (797 patients: $61.7 \%$ ) and mastectomy (393 patients: $30.5 \%)$. We also performed regional comparisons dividing the country in five regions, namely Paris, northwest, northeast, southeast and southwest. Finally, a multivariate analysis was included, allowing predicting the therapeutic choices, such as mastectomy $v s$ CS as well as sentinel node biopsy (SNB) $v s$ axillary dissection (AD) according to age, tumour size (both quantitative variables), or grade and the presence of necrosis (both qualitative variables). A stepwise procedure was used to select variables for the multiple logistic regression analysis.

\section{RESULTS}

\section{Patient data}

A total of 1289 patients were evaluable. Median age was 56 years (range, $30-84$ ). Age distribution was as follows: $4 \%$ below 40 years, $25 \% 40-49,36 \% 50-59,22 \% 60-69$ and $13 \%$ over 70 years. A family history of breast cancer was present in $30 \%$ of patients.

In total, $816(63.3 \%)$ patients were menopausal (median age, 50 years); $52.3 \%$ of them had undergone HRT for a median duration of 7.7 years.

\section{Presentation at diagnosis}

In $87.6 \%$ of patients, DCIS was diagnosed by mammographic abnormality. Only $12 \%$ of patients had clinical symptoms, such as palpable mass, Paget's disease, serosanguineous nipple discharge and/or retraction; such clinical symptoms were present in $9.5 \%$ of CS groups (CS and CS + RT) compared with those in $17.3 \%$ of the mastectomy group.

\section{Mammography findings}

Of 1235 abnormal mammograms, 1227 could be evaluated: 1012 $(82.5 \%)$ showed microcalcifications only, $62(5.6 \%)$ opacity, architectural distortion or increased density and $146(11.9 \%)$ combinations of these features. Of 1156 mammograms that could be evaluated according to the Breast Imaging Reporting and Data System from American College of Radiology (BI-RADS) classification, 107 (9.2\%) were BI-RADS 3, 720 (62.3\%) BI-RADS 4 and 329 (28.5\%) BI-RADS 5.

\section{Preoperative biopsy}

Preoperative needle biopsy was performed in $61.8 \%$ of patients. Vacuum-assisted needle biopsy was performed in $66.4 \%$ of these patients and stereotactic core-needle biopsy in $33.6 \%$.

\section{Histopathology}

The tumour was excised as a single specimen in $94.4 \%$ of patients, but one or more re-excisions proved necessary in $37 \%$ of patients. Tumour size was evaluable in $1062(82.4 \%)$ tumours: $431(40.6 \%)$ $\leqslant 10 \mathrm{~mm}, 291(27.4 \%) 11-20 \mathrm{~mm}$ and $340(32 \%)>20 \mathrm{~mm}$. Median tumour size was $14.5 \mathrm{~mm}$ : $6 \mathrm{~mm}$ for CS, $11 \mathrm{~mm}$ for CS + RT and $35 \mathrm{~mm}$ for mastectomy $(P<0.0001)$. Nuclear grade was low in $21 \%$, intermediate in $38.5 \%$ and high in $40.5 \%$ of tumours.

Excision was considered complete (usually margins $\geqslant 1 \mathrm{~mm}$ ) in $92 \%$ of CS patients and in $88.3 \%$ of CS + RT patients. The corresponding percentages were 3 and $5.8 \%$ for doubtful excision, 4 and $2.4 \%$ for incomplete excision, with 1 and $3.5 \%$ for nonevaluable excision. Tumour-free margins were measured in $66.7 \%$ of CS patients and $70.3 \%$ of CS + RT patients. The margin was $<1 \mathrm{~mm}$ in $10.6 \%(\mathrm{CS})$ and $12.1 \%(\mathrm{CS}+\mathrm{RT}$ ) of patients, $1-3 \mathrm{~mm}$ in $21 \%$ of patients (whether CS or CS + RT), $4-10 \mathrm{~mm}$ in $51.5 \%$ (CS) and $57.1 \%(\mathrm{CS}+\mathrm{RT})$ of patients, and $>1 \mathrm{~cm}$ in $16.7 \%$ (CS) and $10.3 \%(C S+R T)$ of patients. Thus, we do not have any specific analysis of multifocality and multicentricity, but we have the notion of 'residual tumour' on the specimen in case of multiple surgery, maximal tumour size and final margin status to predict the best surgical option (especially mastectomy). Indeed, the definitions of multifocality or multicentricity are often very subjective and confusing, especially in case of several little foci in the same area, but each one separated only by few millimetres.

Steroid hormone receptors were assayed in $31 \%$ of tumours. Oestrogen receptors (ER) were positive in $70 \%$ of patients and progesterone receptors in 59.5\%. Hormonal replacement therapy had no influence on lesion size, architectural subtype and hormone receptor status, but was significantly associated with tumour grade. Indeed, low-grade tumours were found in $26.2 \%$ of women who had undergone HRT and in $18.3 \%$ who had not. Tumours were high grade in $34.2 \%$ (HRT) and $47.6 \%$ (no HRT) of women $(P=0.0004)$.

\section{Treatment}

Out of 1289 patients, 896 (69.5\%) underwent CS and 393 (30.5\%) mastectomy. The $69.5 \%$ undergoing CS could be further classified into $7.8 \%$ who underwent just CS and $61.7 \%$ who received adjuvant RT (89\%). Generally, $70 \%$ of the patients underwent one operation, $27 \%$ two and $3 \%$ three. Residual DCIS foci were found in $59 \%$ of patients undergoing a second or third operation. Mastectomy was performed in $40 \%$ of patients as a first option but in $50 \%$ after one or two lumpectomies, and in $10 \%$ after quadrantectomy. Most patients who underwent multiple operations ended up by having a mastectomy. The number of breast surgical procedures was significantly reduced if a preoperative biopsy (stereotactic core-needle biopsy and more specially vacuum-assisted needle biopsy) was performed (Table 1). The rate of $\mathrm{AD}$ was also significantly reduced by the preoperative biopsy use, whereas the rate of SNB was increased (Table 2). 
Table I Correlation between number of extra surgical procedures and pre-operative biopsy (percent patients)

\begin{tabular}{lccc}
\hline $\begin{array}{l}\text { Number of extra } \\
\text { surgical procedures }\end{array}$ & No biopsy & SCNB & VANB \\
\hline CS and CS+RT & $n=257$ & $n=175$ & $n=334$ \\
I & 72.4 & 83.4 & 92.3 \\
2 or 3 & 27.6 & 16.6 & 7.7 \\
Mastectomy & $n=138$ & $n=91$ & $n=163$ \\
I & 10.1 & 53.8 & 58.3 \\
2 or 3 & 89.9 & 46.2 & 41.7 \\
\hline
\end{tabular}

Abbreviations: $C S=$ conservative surgery; $\mathrm{RT}=$ radiotherapy; $\mathrm{SNCB}=$ stereotactic core-needle biopsy; $\mathrm{VANB}=$ vacuum-assisted needle biopsy. $P<0.000 \mathrm{I}$ for each comparison between treatments according to $\chi^{2}$-test.

Table 2 Influence of pre-operative surgery on axilla surgery (\% of patients)

\begin{tabular}{lccr}
\hline & No biopsy & Previous biopsy & P-value \\
\hline Sentinel node biopsy & 15.4 & 25 & $<0.0001$ \\
Axillary dissection & 14 & 8.2 & 0.0009 \\
\hline
\end{tabular}

Tumour size, nuclear grade, necrosis and age significantly influenced treatment modalities (Table 3). Mastectomy was used to treat $41 \%$ of high-grade tumours vs $15.3 \%$ of low-grade tumours. Generally, $93 \%$ of the patients with tumours $\leqslant 10 \mathrm{~mm}$ were treated by CS $(84.5 \%$ with RT) and $63.2 \%$ of patients with tumours $\geqslant 20 \mathrm{~mm}$ underwent mastectomy. Mastectomy rates were $43 \%$ for comedocarcinoma and $28 \%$ for other lesions $(P<0.0001)$. Conservative surgery was used to treat $1.5 \%$ of comedocarcinoma and $9.5 \%$ of other lesion subtypes $(P<0.0001)$. The multiple logistic regression analysis confirmed that the factors significantly influencing the mastectomy choice were tumour size (OR: 1.088), young age (OR: 0.975$)$ and high or intermediate grade (Table 4 ).

Of 896 women who were treated by CS, 797 (89\%) received adjuvant RT. The median dose administered to the whole breast was $50 \mathrm{~Gy}$. A $10 \mathrm{~Gy}$ boost (median dose) was given to $49 \%$ of patients $(48 \%$ if excision was complete and $63.1 \%$ in case of incomplete or doubtful excision $(P=0.018)$.

Tumour size, nuclear grade, lesion subtype (comedo $v s$ others) and treatment strongly influenced axilla treatment (Table 5). Generally, $21.3 \%$ of patients underwent SNB and $10.4 \%$ AD. The multiple logistic regression analysis showed that sentinel biopsy procedure rates were higher in case of mastectomy, comedocarcinoma subtypes, large tumour size and high-grade lesions (Table 6). The $\mathrm{AD}$ use was significantly and only correlated to the mastectomy option (OR: 5.83; IC 95\%: $3.68-9.24, P<0.001$ ).

Adjuvant hormone therapy was administered to $172(13.4 \%)$ patients; 138 received tamoxifen (80\%), 7 a luteinizing hormonereleasing hormone (LH-RH) agonist and 25 an aromatase inhibitor.

\section{Regional variations in practice}

There are some variations among regions in histopathological diagnosis (e.g., percentage of high-grade lesions, comedocarcinoma subtype and ER assessment) as well as in treatments (Table 7). The mastectomy rate ranged from 35 to $50 \%$ for highgrade DCIS and from 38.5 to $50 \%$ for comedocarcinoma. It varied from 20 to $37 \%$ according to the region. There were also wide regional variations in the delivery of adjuvant RT (81-96\%) and in the administration of adjuvant hormone therapy (6-34\%). Mastectomy rates also varied according to the type of institution (37.4, 32 and $19.4 \%$ in cancer centres, academic or general hospitals and private clinics, respectively, $P<0.0001)$. The corresponding CS + RT rates were $87.3,81.3$ and $94.2 \%$.
Table 3 Influence of tumour size, nuclear grade, necrosis and age on treatment modality (number and percent patients)

\begin{tabular}{|c|c|c|c|c|c|c|c|c|}
\hline & \multicolumn{2}{|c|}{ CS } & \multicolumn{2}{|c|}{ CS+RT } & \multicolumn{2}{|c|}{ Mastectomy } & \multicolumn{2}{|c|}{ Total } \\
\hline & $\mathbf{N}$ & $\%$ & $N$ & $\%$ & $\mathbf{N}$ & $\%$ & $N$ & $\%$ \\
\hline \multicolumn{9}{|l|}{ Tumour size $(p T, m m)^{a}$} \\
\hline$\leqslant 10$ & 62 & 14.4 & 339 & 78.6 & 30 & 7 & 431 & 40.6 \\
\hline $11-20$ & 14 & 4.8 & 223 & 76.6 & 54 & 18.6 & 291 & 27.4 \\
\hline$>20$ & 5 & 1.5 & 120 & 35.3 & 215 & 63.2 & 340 & 32 \\
\hline \multicolumn{9}{|l|}{ Grade $^{b}$} \\
\hline Low & 56 & 20.9 & 171 & 63.8 & 41 & 15.3 & 268 & 21 \\
\hline Intermediate & 30 & 6.2 & 322 & 65.7 & 138 & 28.1 & 490 & 38.5 \\
\hline High & 12 & 2.3 & 294 & 57.1 & 209 & 40.6 & 515 & 40.5 \\
\hline \multicolumn{9}{|l|}{ Necrosis $^{c}$} \\
\hline None necrosis & 68 & 13.4 & 334 & 65.9 & 105 & 20.7 & 507 & 42 \\
\hline No comedo necrosis & 15 & 6.6 & 136 & 59.6 & 77 & 33.8 & 228 & 19 \\
\hline Comedo necrosis & 9 & 1.9 & $27 \mid$ & 57.2 & 194 & 40.9 & 474 & 39 \\
\hline \multicolumn{9}{|l|}{ Age (years) } \\
\hline$<50$ & 26 & 26.2 & 203 & 25.5 & $|4|$ & 35.9 & 370 & 28.7 \\
\hline $50-60$ & 41 & 41.4 & 284 & 35.6 & 136 & 34.6 & 461 & 35.8 \\
\hline $61-70$ & 14 & 14.1 & 198 & 24.8 & 73 & 18.6 & 285 & 22.1 \\
\hline$>70$ & 18 & 18.2 & 112 & 14.1 & 43 & 10.9 & 173 & 13.4 \\
\hline
\end{tabular}

Abbreviations: $\mathrm{CS}=$ conservative surgery; $\mathrm{RT}=$ radiotherapy. Evaluable cases: ${ }^{\mathrm{a}} \mathrm{O} 062$ (82.4\%); ${ }^{b}$ I 273 (98.7\%); and ${ }^{\mathrm{C}} \mathrm{2} 209$ (93.8\%)

Table 4 Mastectomy option influencing factors: multiple logistic regression analysis by stepwise procedure

\begin{tabular}{lcccc}
\hline Variable & WALD value & $\chi^{\mathbf{2}} \boldsymbol{P}$-value & OR & IC 95\% \\
\hline Tumour size $(\mathrm{mm})$ & 187 & $<0.0001$ & 1.088 & $1.075-1.1$ \\
Age (years) & 9.09 & 0.0026 & 0.975 & $0.96-0.99$ \\
Low grade & 6.94 & 0.0084 & 0.497 & $0.29-0.83$ \\
\hline
\end{tabular}

Abbreviation: $\mathrm{OR}=$ odds ratio.

\section{DISCUSSION}

Our survey was conducted to obtain comprehensive and unselected up-to-date data on diagnosis, assessment and treatment of DCIS in France. The 77 physicians who included patients are breast cancer specialists working in different types of institutions (cancer centres, clinics and hospitals), reflecting the current daily practice in our country. However, we may have a small overrepresentation in our study of large centres.

Since 2000, regional breast cancer screening programmes in France have targeted women aged from 50 to 74 years. Ductal carcinoma in situ was diagnosed by mammography in $87.6 \%$ of our patients, but only in $61.2 \%$ of patients under the age of 40 years. This $87.6 \%$ rate of mammographically detected DCIS is slightly higher than the mean $81.5 \%$ rate of infraclinical lesions found in a former review of 909 patients treated for DCIS in Bordeaux) (Barreau et al, 2005). French (Cutuli et al, 2005a, b) and European (Rutgers, 2001) guidelines also recommend preoperative diagnosis. Our study confirmed that preoperative biopsy significantly decreased the number of breast surgical procedures as well as $\mathrm{AD}$ and should be performed routinely (Table 1).

Our mastectomy rate is identical to that reported by two recent American and English studies (30.5\%) (Katz et al, 2005; Dodwell et al, 2007). In the United States, the overall mastectomy rate decreased from $43 \%$ in 1992 to $37 \%$ in 1995 and $28 \%$ in 1999 (Ernster et al, 2000; Baxter et al, 2004; Mokbel and Cutuli, 2006). However, this rate was much higher $(58 \%)$ in a large series from the Netherlands Cancer Institute (Meijnen et al, 2008). Tumour 
size, grade and necrosis are important factors in the decision to perform mastectomy. In our series, mastectomy was performed in $10 \%$ of patients with DCIS $<10 \mathrm{~mm}$ but in $72 \%$ of patients with DCIS $>20 \mathrm{~mm}$, in $11 \%$ of patients with low-grade DCIS but in $54 \%$ with high-grade DCIS. On the other hand, several recent papers have emphasised the high risk of local recurrence (LR) in young women after CS, with or without RT in both retrospective studies

Table 5 SNB and AD practice according to age, treatment and tumour characteristics

\begin{tabular}{|c|c|c|c|c|}
\hline & $\mathbf{N}$ & SNB \% & AD \% & $P$-value \\
\hline \multicolumn{5}{|c|}{ Tumour size $(\mathrm{cm})^{(1)}$} \\
\hline$<10$ & 431 & 11.1 & 5.6 & \multirow{3}{*}{$<0.0001$} \\
\hline $10-20$ & 291 & 18.2 & 10.3 & \\
\hline$>20$ & 340 & 36.3 & 17.3 & \\
\hline \multicolumn{5}{|l|}{ Nuclear grade ${ }^{(2)}$} \\
\hline Low & 268 & 11.2 & 5.2 & \multirow{3}{*}{0.0025} \\
\hline Intermediate & 490 & 18.2 & 10.4 & \\
\hline High & 515 & 29.7 & 13.2 & \\
\hline \multicolumn{5}{|c|}{ Lesion subtype $^{(3)}$} \\
\hline Comedo & 272 & $31.6^{\mathrm{a}}$ & $11.4^{\mathrm{b}}$ & \multirow{2}{*}{$\begin{array}{c}<0.000 \text { I }^{\mathrm{a}} \\
0.6^{\mathrm{b}}\end{array}$} \\
\hline Other & 851 & 18.1 & 10.3 & \\
\hline \multicolumn{5}{|l|}{ Treatment } \\
\hline CS & 99 & 7.1 & 4 & \multirow{3}{*}{$<0.0001$} \\
\hline $\mathrm{CS}+\mathrm{RT}$ & 797 & 12.9 & 5.1 & \\
\hline Mastectomy & 393 & 41.7 & 22.6 & \\
\hline \multicolumn{5}{|l|}{ Age (years) } \\
\hline$<50$ & 370 & $26.8^{c}$ & $10.3^{\mathrm{d}}$ & \multirow{4}{*}{$\begin{array}{c}0.0074^{c} \\
0.5^{d}\end{array}$} \\
\hline $50-60$ & 461 & 20.4 & 10.2 & \\
\hline $61-70$ & 285 & 15.8 & 11.2 & \\
\hline$>70$ & 173 & 20.8 & 9.8 & \\
\hline
\end{tabular}

Abbreviations: $\mathrm{AD}=$ axillary dissection; $\mathrm{CS}$ = conservative surgery; $\mathrm{RT}$ = radiotherapy; $\mathrm{SNB}=$ sentinel node biopsy. Missing values: ${ }^{(1)} 227 ;{ }^{(2)} 16 ;{ }^{(3)} 166 .{ }^{a} P$-value between lesion subtype (comedo versus other) for SNB. ${ }^{b}$-value between lesion subtype (comedo versus other) for $A D$. ${ }^{c} P$-value according to age ( $<50$ vs $>50$ years) for SNB. ${ }^{d} P$-value according to age ( $<50$ vs $>50$ years) for AD.

Table 6 Sentinel node biopsy influencing factors: multiple logistic regression analysis by stepwise procedure

\begin{tabular}{lcccc}
\hline Variable & WALD value & $\chi^{\mathbf{2}} \boldsymbol{P}$-value & OR & IC 95\% \\
\hline Mastectomy & 30.58 & $<0.001$ & 3.127 & $2.088-4.68$ \\
Comedocarcinoma & 6.92 & 0.0085 & 1.64 & $1.13-2.38$ \\
Tumour size (mm) & 9.57 & 0.002 & 1.014 & $1.005-1.023$ \\
Low grade & 7.58 & 0.0059 & 0.438 & $0.243-0.788$ \\
\hline
\end{tabular}

Abbreviation: $O R=$ odds ratio. and randomized trials (Fisher et al, 2001; Solin et al, 2001; Cutuli et al, 2002; Fourquet et al, 2002; Vicini and Recht, 2002; Bijker et al, 2006). These data probably explain our $50 \%$ mastectomy rates in women under the age of 40 years.

In theory, there is no axillary lymph node involvement in DCIS, although a recent review has reported $1.4 \%$ involvement in 1621 patients with pure DCIS (Morrow et al, 2002; Leonard and Swain, 2004). There may, however, be a risk of associated microinvasive foci, especially when the lesion is extensive (McMasters et al, 2002; Moran et al, 2005; Tunon de Lara et al, 2008). This may be a reason why, even though axilla management is pointless, $10.4 \%$ of our patients underwent $\mathrm{AD}$ and $21.3 \%$ underwent SNB. The potential risk of axillary lymph node involvement was probably overestimated by several physicians. The AD practice was highly influenced by tumour size and nuclear grade (Table 5), but especially by the breast surgery type; indeed, the $\mathrm{AD}$ rate was $5 \%$ after CS vs $22.6 \%$ after mastectomy $(P<0.001)$. The global AD rate recorded in an earlier study by French Cancer Centres, including 1223 patients treated from 1985 to 1996 was 51.3\% (Cutuli et al, 2005a,b). Such a steep decrease (from 51.3 to $10.4 \%$ in France) has already been observed in the United States, where the global AD rate decreased from $34 \%$ in 1992 to $15 \%$ in 1999 $(P<0.001)$, but nevertheless still remained high $(30 \%)$ in 1999 in mastectomy patients (Baxter et al, 2004). In another US study (Smith et al, 2006), AD rate ranged from 18 to $28 \%$ across different sites. At present, $\mathrm{AD}$ is useless and should be replaced by SNB. In our study, SNB rate was $12.3 \%$ after CS vs $41.7 \%$ after mastectomy $(P<0.001)$. Finally, a recent French multicentric study (Tunon de Lara et al, 2008) including 116 large DCIS found 4 positive sentinel nodes (3.4\%). Thus, SNB could be proposed in patients treated by mastectomy.

For most authors, complete tumour excision is the key factor in reducing LR after CS (Silverstein et al, 1999; Kell and Morrow, 2005; MacDonald et al, 2005), but can be difficult to achieve. However, there is no clear consensus on the definition of 'complete' excision and adequate margins (Schwartz et al, 2000; Kell and Morrow, 2005). Tumour size and excision quality are factors often omitted in the reports of randomized controlled trials (Bijker et al, 2001) and retrospective studies (Solin et al, 2001). In our recent national practice guidelines (Cutuli et al, 2005a, b), we have defined complete excision as a resection with at least $3 \mathrm{~mm}$ circumferential margins. Approximately $76 \%$ of our patients underwent complete tumour excision according to this criterion. However, some teams consider a $2 \mathrm{~mm}$ margin to be adequate if the patient subsequently receives RT (Kell and Morrow, 2005).

In patients with tumour excision who did not receive RT, the 10-year LR rates ranged from 19 to $27.8 \%$ (Schwartz, 2002). In four randomized controlled trials, the LR rates after CS without RT were 32, 28, 26 and 22\%, with follow-ups ranging from 52 to 120 months (Fisher et al, 2001; Hougton et al, 2003; Bijker et al, 2006; Holmberg et al, 2008). In a French study, the 7 -year LR rate was $32.4 \%$ in patients not receiving RT (Cutuli et al, 2002). In two latest Dutch studies (Schouten Van Der Velden et al, 2007; Meijnen et al, 2008), the 8- and 10-year LR

Table 7 Regional variations in histopathological features and treatment modalities (\% patients)

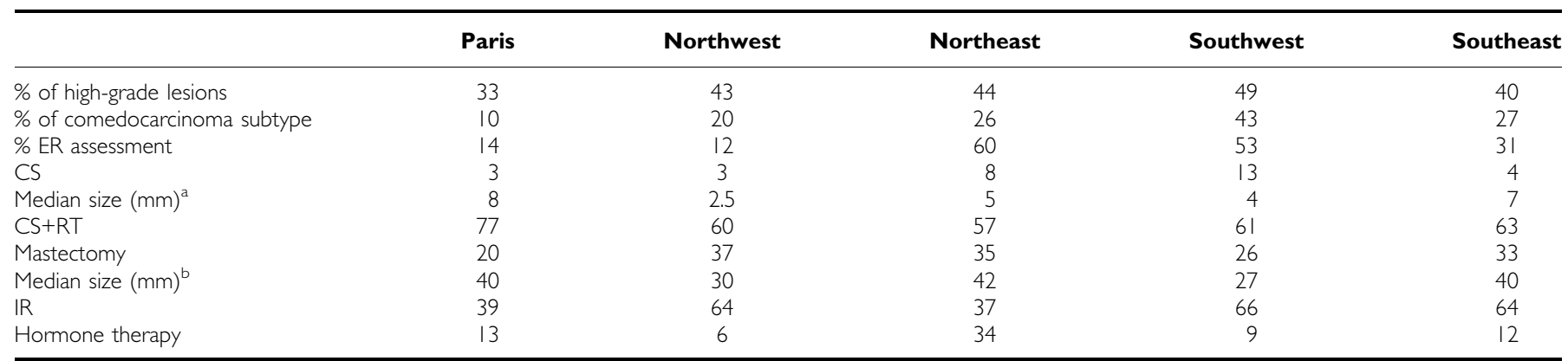

Abbreviations: $C S$ = conservative surgery; $E S=$ oestrogen receptor; $I R=$ immediate reconstruction; $R T=$ radiotherapy. ${ }^{a}$ In patients treated by $C S$ alone. ${ }^{b}$ In patients treated by mastectomy. 
after CS alone were 15.6 and 25\%, respectively. Whole breast irradiation at $50 \mathrm{~Gy}$ after CS for DCIS halved in situ and invasive recurrence rates in earlier quoted trials (Fisher et al, 2001; Hougton et al, 2003; Bijker et al, 2006; Emdin et al, 2006; Holmberg et al, 2008) and several large retrospective studies (Solin et al, 2001; Cutuli et al, 2002; Fourquet et al, 2002; Schouten Van Der Velden et al, 2007; Meijnen et al, 2008). On the other hand, RT administration after wide excision (margins $>1 \mathrm{~cm}$ ) of small low-grade lesions is questioned (Cornfield et al, 2004; MacDonald et al, 2005; Solin et al, 2006; Buchholz et al, 2007, Silverstein et al, 2007). However, this result should be weighed up against the $12 \%$ rate observed at 5 years in a series of low-risk patients (Wong et al, 2006). On the other hand, the Van Nuys Prognostic Index (VNPI), combining tumour size, grade and margin width, was used to select 'low-risk' patients not requiring RT (Silverstein et al, 1996), but was widely criticised in two large American and English studies including 222 and 237 patients, respectively (Boland et al, 2003; MacAusland et al, 2007). A recent Italian study (Di Saverio et al, 2008) including 259 patients also used VNPI and concluded in the absence of statistically significant advantage in the CS + RT vs the CS group. However, the CS + RT group had several unfavourable factors widely increasing LR risk, such as lesion size $>15 \mathrm{~mm}(67 v s$ 30\%) and excision margins $<1 \mathrm{~mm}$ (29 vs $4 \%$ ). These features clearly explain the similarity of LR rates with an 'apparent' inefficiency of RT (7.5\% for CS and $9.5 \%$ for CS + RT). Despite this, other English studies still use VNPI in current practice (Gilleard et al, 2008). Our survey showed that $89 \%$ of patients receive adjuvant RT after CS. A recent study on 1140 screen-detected DCIS in the United Kingdom reported a 57\% 'planned RT' after CS. The RT use was influenced by tumour size (less or more than $15 \mathrm{~mm}$ ), the presence of comedonecrosis and, more particularly, nuclear grade, but paradoxically not by margins (Dodwell et al, 2007). Such differences may show the high confidence of France (and of many centres in the United States and partly the United Kingdom) in randomised trials and large unselected retrospective studies on RT after CS for pure DCIS. Besides, there is clear evidence that boost increases local control in invasive breast cancer, especially in women under the age of 50 years (Bartelink et al, 2001). A boost was given to $49 \%$ of our RT patients compared with $50-75 \%$ of patients in other studies (Cutuli et al, 2002; Fourquet et al, 2002; Solin et al, 2005). A recent study (Omlin et al, 2006) on 375 young women ( $\leqslant 45$ years) treated for pure DCIS showed 28 and 14\% LR rates with and without a $10 \mathrm{~Gy}$ boost. This $50 \% \mathrm{LR}$ reduction rate is identical to that in invasive BC. However, there are several limitations in this study, that is long recruitment period, lack of specification on margin status and types of surgery.

The NSABP-24 trial (Fisher et al, 1999, 2001) found a significant reduction in ipsilateral and contralateral tumours on combining tamoxifen with CS + RT, which was however not confirmed by the results of a randomized trial from the United Kingdom, Australia and New Zealand (Hougton et al, 2003). Tamoxifen was effective in patients with ER-positive tumours only $(37 \%$ of the patients in the NSABP trial) but not in patients with negative margins, absence of necrosis and in women over 50 years (Allred et al, 2002; Fisher et al, 2002). It has some serious side effects (endometrial cancer and thromboembolic events) and various 'minor' others. In a study of 94 patients with DCIS, 20 (21\%) discontinued tamoxifen because of side effects or complications (mainly hot flushes, fatigue, weight gain and gynaecological or digestive symptoms) (Yen et al, 2004). The tumours of $31 \%$ of our patients were assayed for ER and progesterone receptors. The positivity rate was $70 \%$ for ER and $60 \%$ for progesterone receptors, in line with the 64 and 57\% rates, respectively, recorded in a review of 1920 patients (Baxter et al, 2004).

\section{REFERENCES}

Allemand H, Seradour B, Weill A, Ricordeau P (2008) Decline in breast cancer incidence in 2005 and 2006 in France. A paradoxical trend. Bull Cancer 95: $11-15$

Allred DC, Bryant J, Lano S (2002) Estrogen receptor expression as a predictive marker of the effectiveness of tamoxifen in the treatment of
There were important regional differences in histopathological features as well as treatment in our study population (Table 7). The mastectomy rate ranged from 20 to $37 \%$ and the use of RT after CS from 82 to $96 \%$. Tamoxifen use varied widely from $6 \%$ in the northwest to $34 \%$ in the northeast of France. On the other hand, the size of DCIS 'selected' for CS alone ranged from 2.5 to $8 \mathrm{~mm}$. It is also important to point out that wide histopathological variations (partly unexplained) can induce various therapeutic procedures.

Physician discretion and habitual practice rather than actual differences in DCIS probably explain these variations. Indeed, in the above-mentioned UK study (Dodwell et al, 2007), among 69 breast screening units included in the study, wide variations in the use of adjuvant RT were observed, ranging from $0 \%$ in six units to $100 \%$ in two (median: $57.7 \%$ ). The authors explain that such variations in the use of RT reflect the differences in the perception of the risk-benefit relationship in this treatment, and also probably some difficulties to have access to RT facilities (Dodwell and Crellin, 2006). Wide variations have also been recorded in the United States (Ceilley et al, 2004; Katz et al, 2005), especially in the mastectomy rates (range: $26-$ $45 \%$ ) and the use of RT after CS (range: $39-74 \%$ ), and have been confirmed in a recent analysis of the SEER data (Smith et al, 2006). In a retrospective study on 727 patients with DCIS enrolled in the Ontario Breast Screening Program from 1991 to 2000 (Rakovitch et al, 2007), there were also significant regional variations in RT use after BCS, ranging from 43 to $71 \%$ regardless of tumour pathological features, surgeon and hospital volume. On the other hand, some physicians are afraid by possible RT side effects. However, with modern techniques, the 'simple' whole breast irradiation (with or without boost, but without nodal irradiation) delivering 50 Gy in 25 fractions (or equivalent dose) resulted in $<1 \%$ of complications, whereas in case of invasive LR, $15-20 \%$ of the patients finally died by metastatic evolution (Mokbel and Cutuli, 2006; Silverstein et al, 1998). Moreover, in the study reporting the SEER results (Warren et al, 2005), LR rates after CS and CS + RT were 15 and $10.7 \%$, respectively, with a significant increase in breast cancer-related deaths when RT was omitted: 2.7 vs $0.8 \%(P=0.02)$.

In conclusion, randomised controlled trials can provide some answers, even if they are not exempt from criticism (Bijker et al, 2002). Several selection biases have been noted in DCIS trials such as inclusion of benign or microinvasive lesions and lack of compliance with study criteria (lesion size/surgical margins, quality of excision and treatment modalities) (Mokbel and Cutuli, 2006). However, there are now very consistent data confirming the importance of RT to minimise LR risk rates after CS for most DCIS, such as shown in a large study including 23547 women from the California Cancer Registry (Innos and Horn-Ross, 2008). The future trials should identify more clearly selected patients (i.e., older than 60 years, with low-grade lesions under $10 \mathrm{~mm}$ and clear margin over $10 \mathrm{~mm}$ ), in which RT can be safely omitted, and also those with aggressive DCIS requiring mastectomy.

\section{ACKNOWLEDGEMENTS}

We thank Mireille Bigay and Catherine Delva for data management, Diane Penet and Nathalie Heil for technical assistance, Pr Lawrence Solin for his helpful advice and Astra-Zeneca for logistic support.

Supplementary Information accompanies the paper on British Journal of Cancer website (http://www.nature.com/bjc)

DCIS: findings from NSABP protocol B-24. Breast Cancer Res Treat 76(Suppl 1): 536, Abstract 30

Barreau B, De Mascarel I, Feuga C, Mac Grogan G, Dilhuydy MH, Picot V, Dilhuydy JM, Tunon de Lara C, Bussieres E, Scheer I (2005) Mammography of ductal carcinoma in situ of the breast: review 
of 909 cases with radiologic-pathologic correlations. Eur J Radiol 54: $55-61$

Bartelink H, Horiot JC, Poortmans P, Struikmans H, Van Den Bogaert W, Barillot I, Fourquet A, Borger J, Jager J, Hoogenhard W, Collette L, Pierart M (2001) Recurrence rates after treatment of breast cancer with standard radiotherapy with or without additional radiation. $N$ Engl J Med 345: $1378-1387$

Baxter N, Virnig BA, Durham JB, Tuttle TM (2004) Trend in treatment of ductal carcinoma in situ of the breast. J Natl Cancer Inst 96: 443-448

Bijker N, Meijnen P, Peterse JL, Bogaerts J, Van Hoorebeeck I, Julien JP, Gennaro M, Rouanet P, Avril A, Fentiman IS, Bartelink H, Rutgers EJ (2006) Breast conserving treatment with or without RT in ductal carcinoma in situ: ten-year results of European Organisation for Research and Treatment of Cancer randomized phase III trial 10853. A study by the EORTC Breast Cancer Co-operative group and EORTC Radiotherapy group. J Clin Oncol 24: 1-13

Bijker N, Peterse JL, Duchatcau L, Julien JP, Fentiman IS, Duval C, Di Palma S, Simony-Lafontaine J, de Mascarel I, Van de Vijver MJ (2001) Risk factors for recurrence and metastasis after breast-conserving therapy for ductal carcinoma in situ: analysis of European Organization for Research and Treatment of Cancer Trial 10853. J Clin Oncol 19: 2263-2271

Bijker N, Peterse JL, Fentiman IS, Julien JP, Hart AA, Avril A, Cataliotti L, Rutgers EJ (2002) Effects of patient selection on the applicability of results from a randomized clinical trial (EORTC 10853) investigating breast-conserving therapy for DCIS. Br J Cancer 87: 615-620

Boland GP, Chan KC, Knox WF, Roberts SA, Bundred NJ (2003) Value of the Van Nuys Prognostic Index in prediction of recurrence of ductal carcinoma in situ after breast-conserving surgery. Br J Surg 90: $426-432$

Buchholz TA, Haffty BG, Harris JR (2007) Should all patients undergoing breast conserving therapy for DCIS receive radiation therapy? Yes. Radiation therapy, an important component of breast conserving treatment for patients with ductal carcinoma in situ of the breast. J Surg Oncol 95: 610-613

Ceilley E, Jagsi R, Goldberg S, Powell S, Taghian A (2004) The management of ductal carcinoma in situ in North America and Europe. Results of a survey. Cancer 101: 1958-1967

Cornfield DB, Palazzo JP, Schwartz GF, Goonewardene SA, Kovatich AJ, Chervoneva I, Hyslop T, Schwarting R (2004) The prognostic significance of multiple morphologic features and biologic markers in ductal carcinoma in situ of the breast. A study of a large cohort of patients treated with surgery alone. Cancer 100: 2317-2327

Cutuli B, Cohen-Solal-Le Nir C, De Lafontan B, Mignotte H, Fichet V, Fay R, Servent V, Giard S, Charra-Brunaud C, Lemanski C, Auvray H, Jacquot S, Charpentier JC (2002) Breast conserving therapy for ductal carcinoma in situ of the breast: the French Cancer centers' experience. Int J Radiat Oncol Biol Phys 53: 868-879

Cutuli B, Cottu PH, Guastalla JP, Mechin H, Costa A, Jourdan R (2006) A French national survey on infiltrating breast cancer: analysis of clinicopathological features and treatment modalities in 1159 patients. Breast Cancer Res Treat 95: 55-65

Cutuli B, Fourquet A, Luporsi E, Arnould L, Caron Y, Cremoux P, Dilhuydy $\mathrm{JM}$, Fondrinier E, Fourme E, Giard-Lefevre S, Blanc-Onfraoy ML, Lemanski C, Mauriac L, Sigal-Zafrani B, Tardivon A, This P, Tunon de Lara C, Kirova Y, Fabre N (2005a) Standards, options and recommendations for the management of ductal carcinoma in situ of the breast (DCIS): update 2004. Bull Cancer 92: 155- 168

Cutuli B, Lemanski C, Cohen-Solal Le Nir C (2005b) Changes in DCIS features and treatment over a 20 -year period. Analysis of 2512 patients. Breast Cancer Res Treat 94(Suppl. 1), Abstract 6042

Di Saverio S, Catena F, Santini D, Ansaloni L, Fogacci T, Mignani S, Leone A, Gazzotti F, Gagliardi S, De Cataldis S, Taffurelli M (2008) 259 patients with DCIS on the breast applying USC/Van Nuys Prognostic Index: a retrospective review with long-term follow-up. Breast Cancer Res Treat 109: $405-416$

Dodwell D, Clements K, Lawrence G, Kearins O, Thompson CS, Dewar J, Bishop H, Sloane Project Steering Group (2007) Radiotherapy following breast-conserving surgery for screen-detected ductal carcinoma in situ: indications and utilization in UK. Interim findings from the Sloane Project. Br J Cancer 97: 725-729

Dodwell D, Crellin A (2006) Waiting for radiotherapy. BMJ 332: 107-109 Emdin SO, Granstrand B, Ringberg A, Sandelin K, Arnesson LG, Nordgreen H, Anderson H, Garmo H, Holmberg L, Wallgren A (2006) Swedish Breast Cancer Group DCIS: radiotherapy after sector resection for ductal carcinoma in situ of the breast. Results of a randomized trial in a population offered mammography screening. Acta Oncologica 45: $536-543$

Ernster VL, Barclay J, Kerlikowske K, Wilkie H, Ballard-Barbash R (2000) Mortality among women with ductal carcinoma in situ of the breast in the population-based surveillance, epidemiology and end results program. Arch Intern Med 160: 953 -958

Fisher B, Dignam J, Wolmark N, Wickerham DL, Fisher ER, Mamounas E, Smith R, Begovic M, Dimitrov NV, Margolese RG, Kardinal CG, Kavanah MT, Fehrenbacher L, Oishi RH (1999) Tamoxifenin treatment of intraductal breast cancer: National Surgical Adjuvant Breast and Bowel Project B-24 randomised controlled trial. Lancet 353: $1993-2000$

Fisher B, Land S, Mamounas E, Dignam J, Fisher ER, Wolmark N (2001) Prevention of invasive breast cancer in women with ductal carcinoma in situ: an update of the national surgical adjuvant breast and bowel project experience. Semin Oncol 28: 400-418

Fisher B, Land S, Mamounas E, Dignam J, Fisher ER, Wolmark N (2002) Prevention of invasive breast cancer in women with ductal carcinoma in situ: an update of the National Surgical Adjuvant Breast and Bowel Project Experience. In Ductal Carcinoma In Situ of the Breast, Silverstein MJ, Recht A, Lagios M (eds) 2nd edn, pp 432-446. Lippincott William and Wilkins: Philadelphia

Fourquet A, Sigal-Zafrani B, Clough KB (2002) Breast-conserving surgery plus radiation therapy in ductal carcinoma in situ: The Institut Curie Experience. In Ductal Carcinoma In Situ of the Breast, Silverstein MJ, Recht A, Lagios M (eds) 2nd edn, pp 367-372. Lippincott William and Wilkins: Philadelphia

Gilleard O, Goodman A, Cooper M, Davies M, Dunn J (2008) The significance of the Van Nuys Prognostic Index in the management of ductal carcinoma in situ. World J Surg Oncol 6: 61

Holmberg L, Garmo H, Granstrand B, Ringberg A, Arnesson LG, Sandelin K, Karisson P, Aderson H, Emdin S (2008) Absolute risk reductions for local recurrence after postoperative radiotherapy after sector resection for ductal carcinoma in situ of the breast. J Clin Oncol 26: $1247-1252$

Hougton J, George WD, Cuzick J, Duggan C, Fentiman IS, Spittle M (2003) Radiotherapy and Tamoxifen in women with completely excised ductal carcinoma in situ of the breast in the UK, Australia, and New Zealand: randomised controlled trial. Lancet 362: 95-102

Innos K, Horn-Ross PL (2008) Risk of second primary breast cancers among women with ductal carcinoma in situ of the breast. Breast Cancer Res Treat 111: $531-540$

Katz SJ, Lantz PM, Janz NK, Fagerlin A, Schwartz K, Liu L, Deapen D, Salem B, Lakhani I, Morrow M (2005) Patterns and correlates of local therapy for women with ductal carcinoma in situ. J Clin Oncol 23: 3001-3007

Kell MR, Morrow M (2005) An adequate margin of excision in ductal carcinoma in situ. Br J Med 331: 789-790

Leonard G, Swain SM (2004) Ductal carcinoma in situ complexities and challenges. J Natl Cancer Inst 96: 906-920

MacDonald HR, Silverstein MJ, Mabry H, Moorthy B, Ye W, Epstein MS, Holmes D, Silberman H, Lagios M (2005) Local control in ductal carcinoma in situ treated by excision alone: incremental benefit of larger margins. Am J Surg 190: 521-525

MacAusland SG, Hepel JT, Chong FK, Galper SL, Gass JS, Ruthazer R, Wazer DE (2007) An attempt to independently verify the utility of the Van Nuys Prognostic Index for ductal carcinoma in situ. Cancer 110: $2648-2653$

McMasters KM, Chao C, Wong SL, Martin III RC, Edwards MJ (2002) Sentinel lymph node biopsy in patients with ductal carcinoma in situ. A proposal. Cancer 95: 15-20

Meijnen P, Oldenburg HS, Peterse JL, Bartelink H, Rutgers EJT (2008) Clinical outcome after selective treatment of patients diagnosed with ductal carcinoma in situ of the breast. Ann Surg Oncol 15: 235-243

Moran CJ, Kell MR, Kerin MJ (2005) The role of sentinel lymph node biopsy in ductal carcinoma in situ. Eur J Surg Oncol 31: 1105-1111

Morrow M, Strom E, Basset LW, Dershaw DD, Fowble B, Giuliano A, Harris JR, O'Malley F, Schnitt SJ, Singletary SE, Winchester DP (2002) Standard for the management of ductal carcinoma in situ of the breast. Cancer J Clin 52: $256-276$

Mokbel K, Cutuli B (2006) Heterogeneity in DCIS and its effects on management. Lancet Oncol 7: 756-765

Omlin A, Amichetti M, Azria D, Cole BF, Fourneret P, Poortmans P, Naehrig D, Miller RC, Krengli M, Gutierrez Miguelez C, Morgan D, Golberg H, Scandolaro L, Gastelbaum P, Ozsahin M, Dohr D, Christie D, Oppitz U, Abacioglu U, Gruber G (2006) Boost radiotherapy in young 
women with ductal carcinoma in situ: a multicentre, retrospective study of the Rare Cancer Network. Lancet Oncol 7: 652-656

Rakovitch E, Pignol JP, Chartier C, Hanna W, Kahn H, Wong J, Mai V, Paszat L (2007) The management of ductal carcinoma in situ of the breast: a screened population-based analysis. Breast Cancer Res Treat 101: $335-347$

Rutgers EJ, for the EUSOMA Consensus Group (2001) Quality control in the locoregional treatment of breast cancer. Eur J Cancer 37: $447-453$

Schouten Van Der Velden AP, Van Vugt R, Van Dijck JA, Leer JW, Wobbes $\mathrm{T}$ (2007) Local recurrences after different treatment strategies for ductal carcinoma in situ of the breast: a population-based study in the East Netherlands. Int J Radiat Oncol Biol Phys 69: 703-710

Schwartz GF (2002) Treatment of subclinical ductal carcinoma in situ of the breast by local excision and surveillance: an update personal experience. In Ductal Carcinoma In Situ of the Breast, Silverstein MJ, Recht A, Lagios M (eds) 2nd edn, pp 308-321. Lippincott William and Wilkins: Philadelphia

Schwartz GF, Solin LJ, Olivotto IA, Ernster VL, Pressman PL (2000) Consensus Conference on the treatment of in situ ductal carcinoma of the breast, April 22-25 (1999). Human Pathol 31: 131-139

Silverstein MJ, Lagios MD, Craig PH, Waisman JR, Levinski BS, Colburn WJ, Poller DN (1996) A prognostic index for ductal carcinoma in situ of the breast. Cancer 77: 2267-2274

Silverstein MJ, Lagios MD, Groshen S, Waisman JR, Lewinski BS, Martino S, Gamagami P, Colburn WJ (1999) The influence of margin width on local control of ductal carcinoma in situ of the breast. N Engl J Med 340: $1455-1461$

Silverstein MJ, Lagios MD, Martino S, Lexinsky BS, Craig PH, Beron PJ, Gamagami P, Waisman JR (1998) Outcome after invasive local recurrence in patients with ductal carcinoma in situ of the breast. J Clin Oncol 16: $1367-1373$

Silverstein MJ, Lagios MD (2007) Should all patients undergoing breast conserving therapy for DCIS receive radiation therapy? No. One size does not fit all: an argument against the routine use of radiation therapy for all patients with ductal carcinoma in situ of the breast who elect breast conservation. J Surg Oncol 95: 605-609
Smith GL, Smith BD, Haffty BG (2006) Rationalization and regionalization of treatment for ductal carcinoma in situ of the breast. Int J Rad Oncol Biol Phys 65: $1397-1403$

Solin L, Fourquet A, Vicini F, Taylor M, Olivotto IA, Haffty B, Storm EA, Pierce LJ, Marks LB, Bartelink H, Mc Neese MD, Jhingran A, Wai E, Bijker N, Campana F, Hwang WT (2005) Long-term outcome after breast conservation treatment with radiation for mammographically detected ductal carcinoma in situ of the breast. Cancer 1003: 1137-1146

Solin LJ (2006) Is excision alone adequate treatment for low-risk ductal carcinoma in situ of the breast? J Clin Oncol 24: 1017-1019

Solin LJ, Fourquet A, Vicini F, Haffty B, Taylor M, Mc Cormick B, Mc Neese M, Pierce LJ, Landmann C, Olivotto IA, Borger J, Kim J, De la Rochefordiere A, Schultz DJ (2001) Mammographically detected ductal carcinoma in situ of the breast treated with breast-conserving surgery and definitive breast irradiation long-term outcome and prognostic significance of patient age and margin status. Int J Radiat Oncol Biol Phys 50: $991-1102$

Tunon de Lara C, Giard S, Buttarelli M, Blanchot J, Classe JM, Baron M, Monnier B, Houvenaeghel G (2008) Sentinel node procedure is warranted in ductal carcinoma in situ with high risk of occult invasive carcinoma and microinvasive carcinoma treated by mastectomy. Breast J 14: 135 - 140

Vicini FA, Recht A (2002) Age at diagnosis and outcome for women with ductal carcinoma in situ of the breast: a critical review of the literature. J Clin Oncol 20: 2736-2744

Warren JL, Weaver DL, Bocklage T, Key CR, Platz CE, Cronin KA, BallardBallash R, Willey SC, Harlan LC (2005) The frequency of ipsilateral second tumours after breast-conserving surgery for DCIS. A populationbased analysis. Cancer 104: $1840-1848$

Wong JS, Kaelin CM, Troyan SL, Gadd MA, Gelman R, Lester SC, Schnitt SJ, Sgroi DC, Silver BJ, Harris JR, Smith BL (2006) Prospective study of wide excision alone for ductal carcinoma in situ of the breast. J Clin Oncol 24: $1031-1036$

Yen TW, Hunt KK, Mirza NQ, Thomas ES, Singletary SE, Babiera GV, Meric-Bernstam F, Buchholz TA, Feig BW, Ross MI, Ames FC, Theriault RL, Kuerer HM (2004) Physician recommendations regarding tamoxifen and patient utilization of tamoxifen after surgery for ductal carcinoma in situ. Cancer 100: $942-949$

\section{Appendix \\ DCIS FRENCH SURVEY}

Other participants: Achard JL, Clermont-Ferrand; Amalric F, Marseille; Antoine EC, Neuilly; Audrin O, Toulon; Avigdor S, Orleans; Bobin JY, Pierre-Benite; Body G, Tours; Bonnier P, Marseille; Bons-Rosset F, Nimes; Botton A, Pontoise; Bouteille C, St Etienne; Brandone JM, Marseille; Bremond A, Lyon; BrunaudCharra C, Vandoeuvre-les-Nancy; Cailleux PE, Tours; Campana F, Paris; Caquot LM, Reims; Cellier P, Angers; Charvolin JY, Lille; Chevelle C, Toulouse; Chirat E, Meudon-la-Forêt; Cohen M, Aubagne; Cohen-Solal C, Saint-Cloud; Cretin J, Ales; Cuisenier J, Dijon; Cuvier C, Paris; Dauce JP, Rouen; Dohollou N, Bordeaux; Doudi-Gaci Z, Nantes; Fayolle M, Fontainebleau; Fourneret P, Grenoble; Fric D,
Grenoble; Jaubert D, Bordeaux; Jonveaux E, Charleville; Kamioner D, Trappes; Ladonne JM, Rouen; Lavie M, Montpellier; Leduc B, Brives la Gaillarde; Lefranc JP, Paris; Levy C, Caen; Lucas B, Brest; Mandet J, Lille; Marie G, Cherbourg; Mathevet P, Lyon; Mermet J, Chambery; Methin A, Metz; Michaux JP, Cucq; Mongodin, Montelimar; Namer M, Mougins; Orfoeuvre H, Bourg-en-Bresse; Pariente F, Niort; Payan R, Grenoble; Quetin P, Strasbourg; Remuzon P, Dax; Resbeut M, Toulon; Rohart-De Cordoue S, Lille; Romieu G, Montpellier; Routiot T, Nancy; Rozec C, Thiais; Salmon R, Paris; Sautiere JL, Besançon; Serin D, Avignon; Touboul E, Paris; Travade A, Clermont-Ferrand; Vaini V, Aix-en-Provence; Vilcoq J, Paris 